\title{
Hourly and seasonal variations in the area preferences of dairy cows in freestall housing
}

\author{
S. Uzal Seyfi ${ }^{1}$ \\ Department of Farm Structures and Irrigation, Faculty of Agriculture, Selcuk University, Konya 42079, Turkey
}

\begin{abstract}
Barn designs that promote animal comfort and that reflect preferences of dairy cattle play an important role in increasing animal production. This study was performed in freestall barn housing in Konya (Turkey) to determine the hourly and seasonal variation occurring in the barn area preferences of dairy cows. Behaviors of dairy cows were observed in a freestall barn at a commercial dairy farm from 2006 to 2007 using continuous video data ( $24 \mathrm{~h}$ per $\mathrm{d})$. The behaviors of the cows in the barn were videotaped for a total of $40 \mathrm{~d}(960 \mathrm{~h})$ over 4 seasons (10 d for each season) using a 60-min scan sampling technique. The study design included the hourly and seasonal rates of usage of 5 different parts of the barn area. In addition, temperature and humidity were measured on an hourly basis. The values of the cow comfort index, cow stress index, and stall usage index (SUI) were calculated. All behavioral phenotypes were analyzed with a factorial experimental design. The relationship between the barn area preferences of the dairy cattle and the climatic data for the barn area was significant. The open area (a courtyard) was used at a higher rate by dairy cattle for resting, standing, and walking. In addition, the courtyard area was preferred to the freestalls for resting or lying. The rates of usage of the courtyard during autumn, winter, spring, and summer were $39.0,20,66.1$, and $52.2 \%$, respectively. The usage rates of the stalls for these seasons were $22.5,35.7,4.6$, and $8.6 \%$, respectively. The cow comfort index values for autumn, winter, spring, and summer were $0.19,0.29,0.03$, and 0.05 , respectively. The cow stress index values for these seasons were $0.27,0.29$, 0.23 , and 0.22 , respectively. The qualities and size of the barn areas should allow comfortable movement of the animals. And, it is very important that new barn designs incorporate area preferences and the comfort of the cattle rather than high-cost investments.
\end{abstract}

Key words: cow behavior, dairy housing, freestall use index, cow stress index

Received April 13, 2012.

Accepted October 10, 2012.

${ }^{1}$ Corresponding author: seldauzal@selcuk.edu.tr

\section{INTRODUCTION}

To increase animal welfare and animal production, it is important to determine the effects of the barn system and climatic conditions on the behavior of cattle and on the use of barn areas by the cattle. Behavior is considered an indicator of animal welfare (Absmanner et al., 2009). All around good animal welfare takes into account animal functioning (good health and productivity), animal feeling (absence of pain, fear, and stress), and animal living according to natural behaviors (Weary and Fraser, 2006). The way in which a barn is constructed can allow animals to perform their natural behaviors or can restrict the performance of these behaviors (Endres and Barberg, 2007). A freestall barn system is a type of barn plan that contributes to the welfare of the animals by allowing the cows to perform their natural behaviors and by offering them freedom of movement. The evaluation of the positive and negative aspects of this barn plan and the consideration of these issues in the design of alternative barn systems is important in terms of animal welfare and productivity (Uzal, 2008). The development of alternative barn systems for dairy cows is becoming increasingly important because of the potential improvements in efficiency. During recent years, researchers have conducted analyses of low-cost alternative barn systems that provide potential benefits by considering the comfort of the cattle. Such research has become increasingly frequent worldwide (Barberg et al., 2007; Tucker et al., 2007).

Researchers have reported that the environmental conditions in animal barns have significant effects on animal welfare (Hayasaka et al., 2002; Frazzi and Calegari, 2003; Tucker et al., 2007). Temperature (BrownBrandl et al., 2003; Calamari et al., 2003) and humidity (Calamari et al., 2003) are environmental conditions and can significantly affect the behavior of animals (Provolo and Riva, 2008; WMO, 2012). Dairy cows can adapt to a wide range of climatic conditions. However, they show the best production and performance under particular environmental conditions, termed the appropriate temperature (Provolo and Riva, 2008). Webster (1994) reported the appropriate temperatures for dairy cows as 10 to $20^{\circ} \mathrm{C}$. Inappropriate environmental condi- 
tions cause stress in dairy cows, and the productivity of the animals decreases as a result (Collier et al., 2003; WMO, 2012). These negative effects can be overcome by the design of comfortable barn areas that incorporate considerations of animal welfare (Uzal and Ugurlu, 2010a).

An inverse relationship exists between stress and efficiency in organisms. Animals that are under stress use a considerable portion of their energy to eliminate the stress factor to which they are exposed. This expenditure of energy causes a decrease in animal productivity (Adams, 1992). Livestock buildings should be designed to eliminate stress factors and to provide comfort to animals. Suitable designs can eliminate negative influences in animal barns, creating healthy living and production areas for cows. Stress sources can be classified into 4 groups: climatic, structural, social, and other factors (e.g., noise and dust; Ugurlu and Uzal, 2004). Empirical data about animal behavior in different environmental conditions can contribute to the understanding of the relationship between animal behavior and the requirements for the design of barn areas. Thus, new barn designs can be developed, and animal comfort can be maintained at an optimum level in livestock buildings (Uzal and Ugurlu, 2009).

The behavior of cattle is considered to represent a good indicator of animal welfare (Overton et al., 2002) and animal comfort. Indices based on the time spent by cows in different activities (e.g., lying, standing, eating, and drinking) have been used for this purpose by several authors (Overton et al., 2003; Cook et al., 2005). The daily behavior patterns of animals have been used to determine the benefits of different bedding and housing alternatives by several authors (Damasceno et al., 1999; Haley et al., 2000; Fregonesi et al., 2007).

The literature contains remarkably few studies on the relationship between environmental conditions and animal behaviors (Cook et al., 2007). Zähner et al. (2004) studied the resting behaviors of the animals in 4 herds of Swedish dairy cattle under different environmental conditions. They reported that cattle spend less time lying down in warm weather. Shultz (1984) reported a linear relationship between temperature and the rate of standing by cattle in a behavioral study conducted in livestock buildings. In a freestall barn study, Overton et al. (2002) reported a negative relationship between the resting behavior of cattle and temperature.

To evaluate the performance of the housing and management system used for a herd, observations of the behavior of the cows over a few days could be informative. In fact, the differences among seasons and the effect of external environmental conditions (e.g., temperature and humidity) affect the daily behavioral pattern of the herd (St-Pierre et al., 2003). Previous studies in the literature addressed a narrow range of topics, such as the effects of a barn planning system or of the barn area preferences of cattle on 1 or 2 behavior types.

The aims of this study were as follows: (1) to investigate the daily, hourly, and seasonal variation occurring in the barn area (courtyard area, freestalls, feeding area, watering area, and alley) preferences of dairy cattle; (2) to investigate the relationship between the climatic conditions in animal barns and the barn area preferences of dairy cattle; and (3) to determine new alternative barn design criteria appropriate for animal welfare.

\section{MATERIALS AND METHODS}

\section{Housing and Animals}

The study was conducted between October 2006 and August 2007 at a Holstein dairy cattle farm located in Konya (Turkey). The farm's 2.4-ha area included courtyards, cubicles, service roads, a feeding area, watering areas, and a management building. Of the 150 cattle on the farm, 70 were dairy cows, whereas the remaining animals were heifers and calves. As a component of farm management, animals were maintained in different paddocks based on milk yield. The paddock used in this study contained cows in the middle phase of their lactation period. A total of 18 to 22 animals (autumn: 18, winter: 22, spring: 20, and summer: 22 ) were maintained in this paddock. Different cows were used during each season. The animals were able to move freely in their pens.

The cows were kept in freestall dairy housing (with cubicles in 4 lines, head-to-head). A freestall dairy barn was selected to provide freedom of movement to the cattle in this study. In the barn facilities, the freestall width, freestall length, neck rail height, neck rail distance from the curb, slope of cubicles (front-to-back), feeding length, courtyard area stocking density, and feed alley width were $1.15 \mathrm{~m}, 2.30 \mathrm{~m}, 1.10 \mathrm{~m}, 1.68 \mathrm{~m}$, $2 \%, 0.82 \mathrm{~m}$ per cow, $16.40 \mathrm{~m}^{2}$ per cow, and $4.40 \mathrm{~m}$, respectively. The bedding surface of the freestalls was rubber. The stalls were cleaned once per week or twice a month.

The mean \pm standard deviation of the number of lactations, the milk yield, and DIM were $1.5 \pm 0.5$, $18.0 \pm 2.6 \mathrm{~kg} / \mathrm{d}$, and $251 \pm 142$ for autumn; $1.6 \pm$ $0.5,20.0 \pm 3.1 / \mathrm{d}$, and $206 \pm 120$ for winter; $1.6 \pm 0.5$, $21.0 \pm 2.6 \mathrm{~kg} / \mathrm{d}$, and $155 \pm 123$ for spring; and $1.5 \pm$ $0.5,19.7 \pm 2.5 \mathrm{~kg} / \mathrm{d}$, and $194 \pm 129$ for summer, respectively. All animals in this study were fed a mixture of corn silage and grass silage, concentrated feed, and hay supplemented with a concentrated feed. Feed was delivered to the animals twice per day, and the forage 
was swept to clean the feeding area twice per day. The animals were milked twice per day, at approximately 0600 and $1800 \mathrm{~h}$.

\section{Video Recording Equipment and Climate Measurements}

A video recording system was placed in the barn to observe the behavior of the animals (Aycan Alarm Security Joint Stock Co., Samsun, Turkey). The system included 4 digital color day/night vision cameras [one-third-inch Sony HQ1 color CCD sensor, $752(\mathrm{H}) \times$ $582(\mathrm{~V})$ pixels, minimum light sensitivity; Sony Corp., Taipei, Taiwan] and 1 portable 8-channel recording device (15-inch LCD display, 8 sensor inputs, 500 GB memory). Four cameras were placed in the outside and inside areas of the barn (2 cameras for outside area and 2 cameras for inside area). The cameras were linked to the recording device. A digital temperature-humidity meter (climatic device) was used to obtain climatic data for the barn area (temperature measurement range: $-40^{\circ} \mathrm{C}$ to $+100^{\circ} \mathrm{C}$, resolution: $0.03^{\circ} \mathrm{C}$, precision: $\pm 0.3^{\circ} \mathrm{C}$; $\mathrm{RH}$ measurement range: 0 to $100 \% \mathrm{RH}$, resolution: $0.4 \%$, precision: $\pm 3 \%$; Hobo Pro data logger; Onset Computer Corp. Inc., Pocasset, MA). The climatic devices were located at 9 different points in 3 different areas of the farm: the resting, courtyard, and outside areas (Figure 1). The devices were at a level slightly above the cow's height, as suggested by Robarge et al. (2002), Phillips et al. (2004), and Walker et al. (2006). Each device was fixed to a box for protection from direct sunlight. A detailed plan of the experimental facility, including the dairy barn and the measurement devices, is shown in Figure 1.

\section{Observation Periods and Climatic Data Collection}

The behaviors of the dairy cattle were recorded on 10 predefined days during each season. These observations included a total of $40 \mathrm{~d}, 960 \mathrm{~h}$, and 4 seasons. A video system that allowed continuous recording was used for the observations. The operational timetable for the study, including the periods of observation and the number of cows observed during each period, is specified in Table 1. The area preferences of the cows were determined from 60-min scan samples for $10 \mathrm{~d}$ per season in accordance with methods used in previous research (Martin and Bateson, 1993; Mitlöhner et al., 2001; Hernández and Calmenares, 2006; Table 1). To eliminate the effects of variation among observers, the behavior of the cattle was evaluated by a single observer (S. Uzal Seyfi). The barn area preferences of the cattle for daily activity (lying, standing, feeding, and watering) were noted individually on the barn plans and transferred to an Excel spreadsheet (Microsoft Corp., Redmond, WA) for each area.

\section{Phenotypes}

The cow comfort index (CCI), the cow stress index (CSI), and the freestall use index (SUI), 3 indices used to analyze behavioral data in cows, were the phenotypes of interest in this study. The CCI is calculated for cows in stalls and is given by the proportion of these cows observed to be lying down (Cook et al. 2005). The SUI, the proportion of all eligible cows observed to be lying down, was defined as the total number of cows lying in the freestalls divided by the total number of cows in the experimental paddock of the barn that were not eating or watering during that time period (Overton et al., 2002). The CSI was calculated as the number of cows observed standing (not lying and eating) divided by the total number of cows in the barn (Mattachini et al., 2011). The 3 behavioral indexes (comfort index values) were calculated on an hourly basis for all observation periods and all seasons.

\section{Statistical Analyses}

A factorial analysis in a random-parcel experimental design was applied to determine the effects of differences in the seasonal period and the time period on the area preferences of dairy cattle. Minitab 14 software (release 12.2; Minitab Inc., New York, NY) was used for this analysis. All data collected from the dairy barn area in all seasons were evaluated with an ANOVA (Minitab 14).

\section{RESULTS AND DISCUSSION}

\section{Behavior Indexes}

The seasonal distribution of the mean values of the behavior indexes (the 3 comfort-related index values) is given in Table 2. The CCI was highest in the winter (0.29) and lowest (0.03) in the spring, the CSI was lowest in the summer and highest in the winter, and the SUI was highest in the winter and lowest in the spring. The highest values of the SUI occurred during relatively cold seasons. In the winter, because the barn doors were closed after the afternoon milking and the cattle then had to use the stalls, the SUI increased. Provolo and Riva (2008) reported CLI (the same index as the CCI) values of $54 \%$ for August, $64 \%$ for October, $65 \%$ for December, and $80 \%$ for January. The same researchers reported SUI values for the same months of $61,73 \%, 78$, and $89 \%$, respectively; they also reported CSI values of $31,21,18$, and $10 \%$, respectively, for 
Table 1. The periods of observation of dairy cattle behavior and the number of cows observed

\begin{tabular}{llcc}
\hline Season & Observation period & $\begin{array}{c}\text { Number of cows in } \\
\text { experimental paddocks }\end{array}$ & $\begin{array}{c}\text { Number of } \\
\text { hours analyzed }\end{array}$ \\
\hline Autumn & October 25 to 3 November 3, 2006 & 18 & 240 \\
Winter & February 12 to 21, 2007 & 22 & 240 \\
Spring & April 21 to 30, 2007 & 20 & 240 \\
Summer & July 24 to August 2, 2007 & 22 & 240 \\
\hline
\end{tabular}

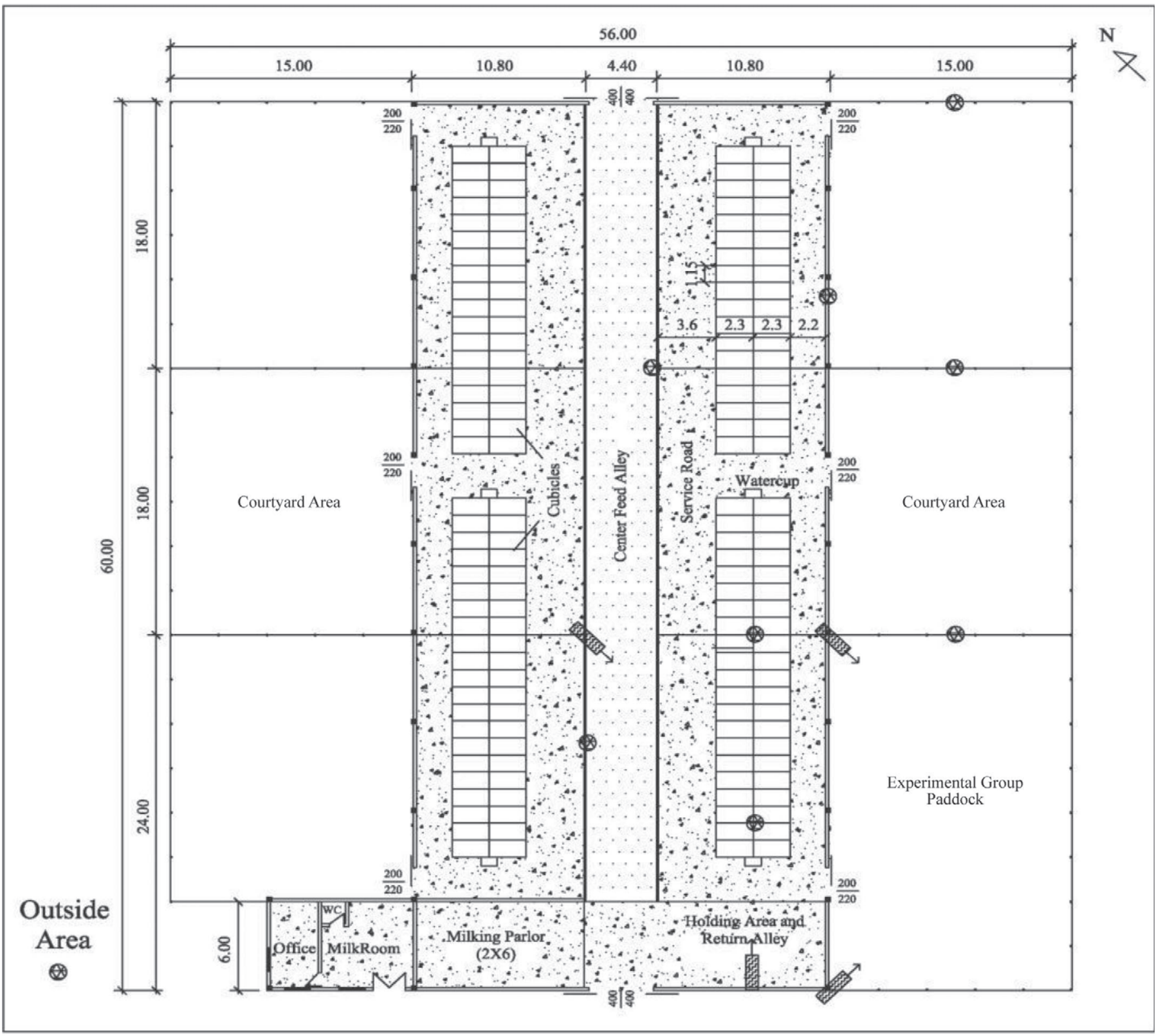

\footnotetext{
- Temperature and Humidity Measurement Points

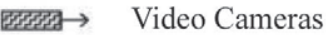

Figure 1. Plan of the freestall dairy barn (distances in meters) and measurement points for air temperature and humidity. 
Table 2. The seasonal variation in the mean values of cow behavior indexes in freestall dairy barns

\begin{tabular}{lccc}
\hline Item & $\begin{array}{c}\text { Cow comfort } \\
\text { index (CCI) }\end{array}$ & $\begin{array}{c}\text { Cow stress } \\
\text { index (CSI) }\end{array}$ & $\begin{array}{c}\text { Freestall use } \\
\text { index (SUI) }\end{array}$ \\
\hline Autumn & 0.19 & 0.27 & 0.26 \\
Winter & 0.29 & 0.29 & 0.40 \\
Spring & 0.03 & 0.23 & 0.04 \\
Summer & 0.05 & 0.22 & 0.07 \\
Averaged & 0.14 & 0.25 & 0.19 \\
\hline
\end{tabular}

those months. These values indicate that the CCI and SUI values increased and the CSI value decreased as the temperature decreased. These values are consistent with the behavioral index values found in the present study.

Many studies have found that cows with high levels of resting behavior have higher milk yields (Grant and Albright, 2000; Matzke, 2003; Uzal and Ugurlu, 2010a,b,c.). High CCI values in cattle indicate increased animal welfare. However, the occurrence of high values during cold seasons and low values during warm seasons is a result of the increased use of the stalls during the cold periods. Uzal and Ugurlu (2010a) analyzed the effect of the barn planning system on the time budgets of cattle and reported that the longest duration of resting behavior was observed in the spring and in the summer $(12.12 \pm 0.56 \mathrm{~h} / 24 \mathrm{~h}$ for the spring and $11.55 \pm 0.51 \mathrm{~h} / 24 \mathrm{~h}$ for the summer in freestall barns). The apparent discrepancy between the results of the current study and the data in the literature is a result of the tendency of the cattle to prefer the courtyard area to the stalls for resting during warm periods. This result also indicates that the cattle find open areas more comfortable than stalls. The finding by the cur- rent study that the SUI values were relatively high in the winter and that the spring and summer values were approximately one-tenth of the winter values supports this conclusion.

\section{The Seasonal and Hourly Variation in the Densities of Barn Area Usage}

The season had a significant effect on barn area usage $(F=7.16, P<0.001)$. In addition, the barn area $(F=523.28, P<0.001)$, the hour of the day $(F=5.17$, $P<0.001)$, and the interaction between the barn area and the hour of the day $(F=26.24, P<0.001)$ all had significant effects on barn area usage. The distribution of the mean temperature and relative humidity $(\mathbf{R H})$ values and the distribution of the barn area preferences over the experimental periods during all seasons (based on $40 \mathrm{~d}$ of observation, $10 \mathrm{~d}$ during each season) are shown in Figures 2, 3, 4, 5, 6, 7, 8, and 9.

The cattle generally preferred to use the courtyard area during the autumn (39\%, on average; Figure 2). The use of the feeding area and the use of the courtyard area were inversely correlated. Similarly, the use of the feeding area and the use of the stalls were inversely correlated. The highest value $(75 \%)$ of courtyard area usage was observed at 1600 and $1700 \mathrm{~h}$, whereas the lowest value of courtyard area usage was observed at 0700 and $1900 \mathrm{~h}$ (shortly after morning and afternoon milkings). The highest value $(80.5 \%)$ of feeding area usage was observed at $0800 \mathrm{~h}$, whereas the lowest value of feeding area usage was seen at $0400 \mathrm{~h}$. The highest value $(41.1 \%)$ of cubicle usage was observed at 0300 and 04:00 $\mathrm{h}$. The animals began to feed after milking (morning milking at $0510 \mathrm{~h}$; afternoon milking at 1710

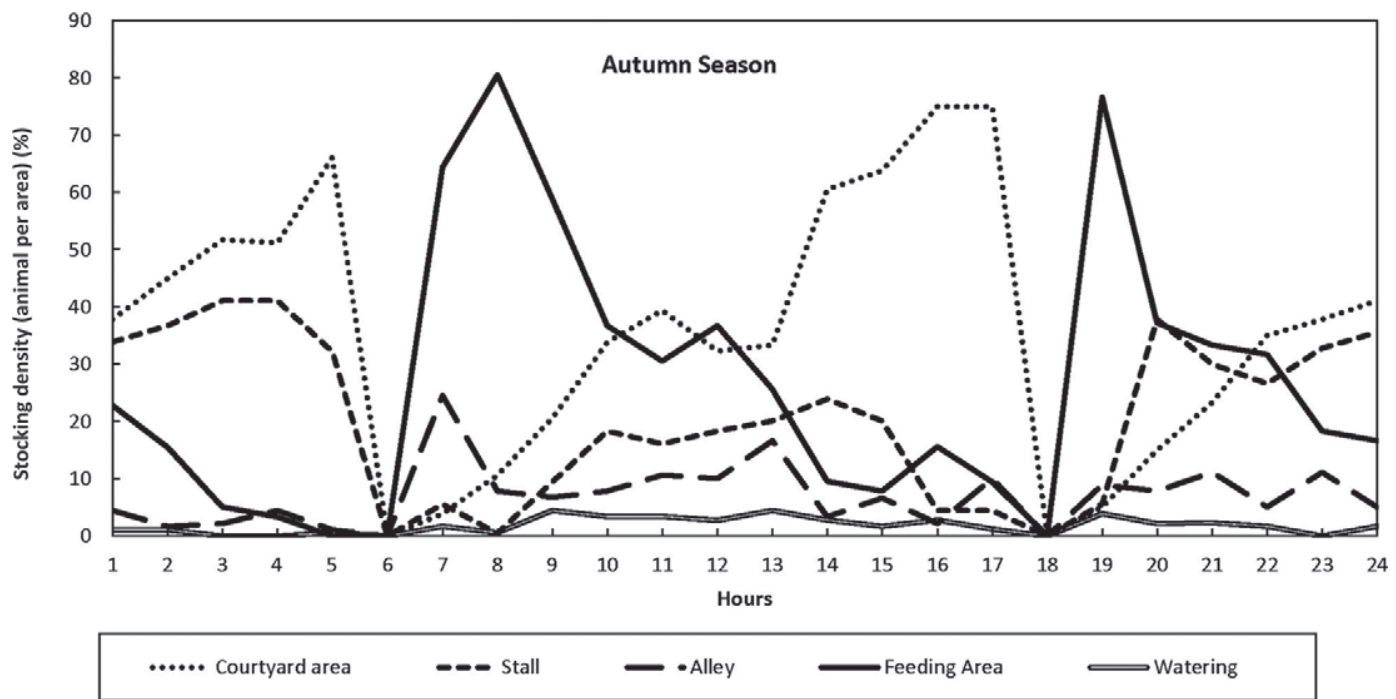

Figure 2. Distribution of mean hourly barn area usage by dairy cattle in the autumn. 


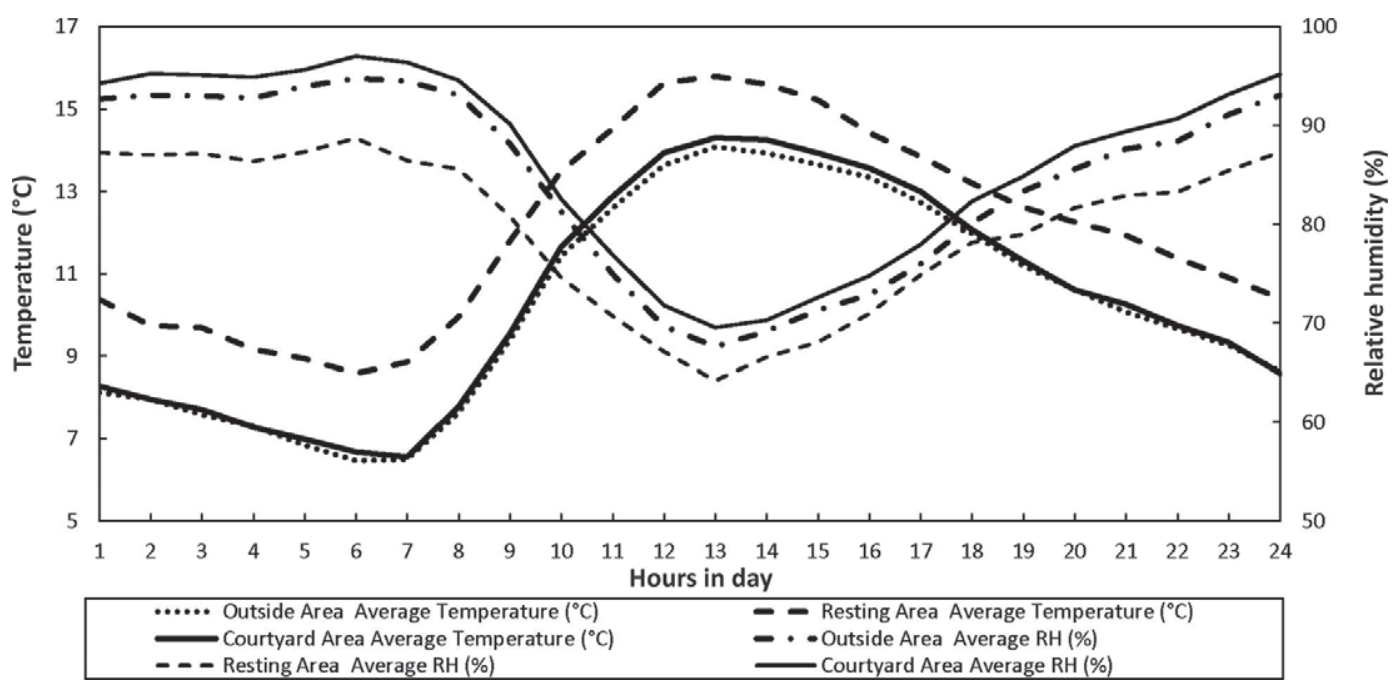

Figure 3. Distribution of hourly mean temperature and relative humidity $(\mathrm{RH})$ values for different barn areas in the autumn.

h). After feeding, a significant proportion of the cattle (approximately 60\%) preferred the courtyard area for resting, whereas a small proportion (approximately $20 \%$ ) preferred to use the stalls. For this reason, from 0700-1200 and 1900-2200 h, when the feeding rate was high, the use of the courtyard area decreased to $3.9 \%$, whereas the use of the stalls decreased to $5.5 \%$. The use of these areas increased as the feeding rate decreased.

The cattle preferred to use the courtyard area in the autumn, particularly during the afternoon (between 1400 and $1700 \mathrm{~h}$ ). The temperature of the courtyard area reached its maximum value between these hours (mean, maximum, minimum values: 13.7, 20.0, and $8.0^{\circ} \mathrm{C}$, respectively). The $\mathrm{RH}$ values were found to be appropriate (Ekmekyapar, 1991) for the cattle $(74 \%$, on average) in this area (Figure 3). The mean temperature of the closed area (the area composed of the cubicles, the service road, and the feeding area) was approximately $15^{\circ} \mathrm{C}$ (maximum and minimum 22.9 and $8.9^{\circ} \mathrm{C}$, respectively), and the $\mathrm{RH}$ value was approximately $70 \%$, measured during the same hours (Figure 3). Between 1400 and $1700 \mathrm{~h}$, the temperature of the closed area was $1^{\circ} \mathrm{C}$ higher, on average, than the temperature of the courtyard area. Nevertheless, the cattle preferred to use the courtyard area. Most likely, the cattle preferred open areas, and the temperature in the courtyard area was appropriate for the cattle during this time period (Okuroğlu and Yağanoğlu, 1993; Webster,

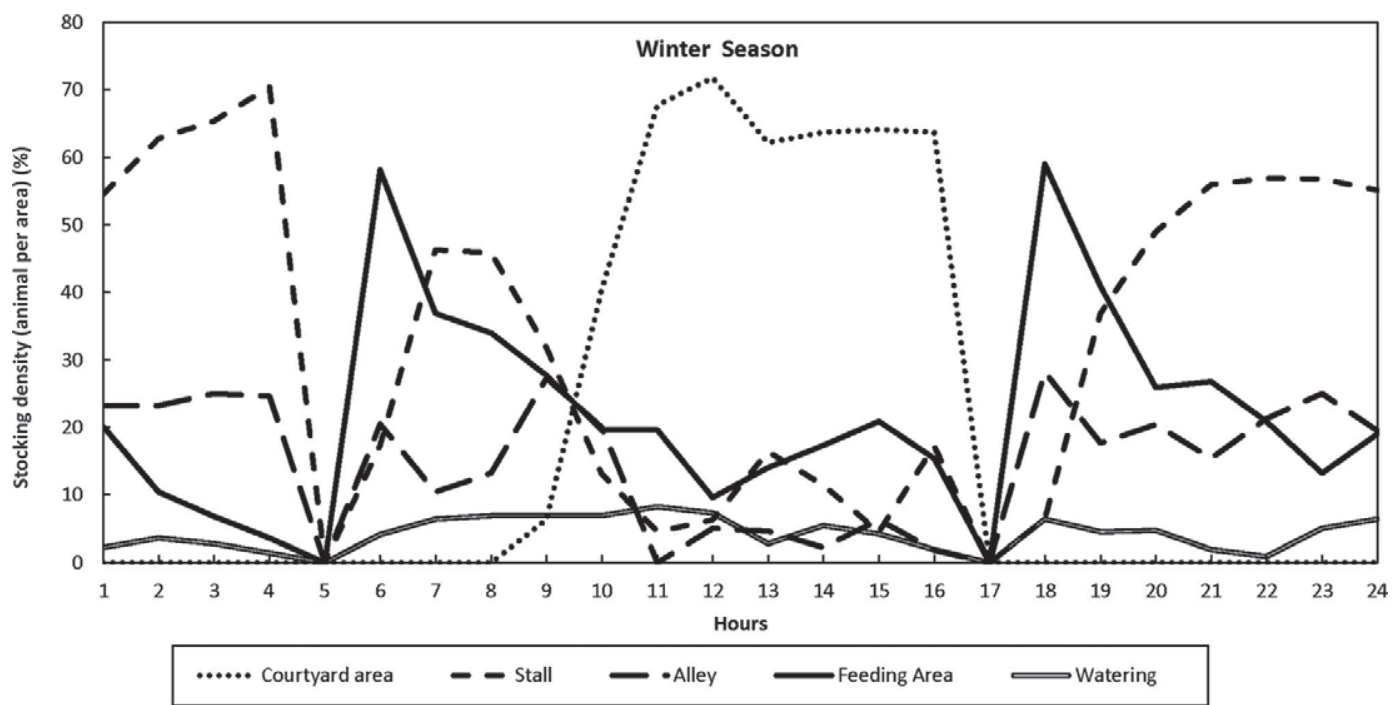

Figure 4. Distribution of mean hourly barn area usage by dairy cattle in the winter. 


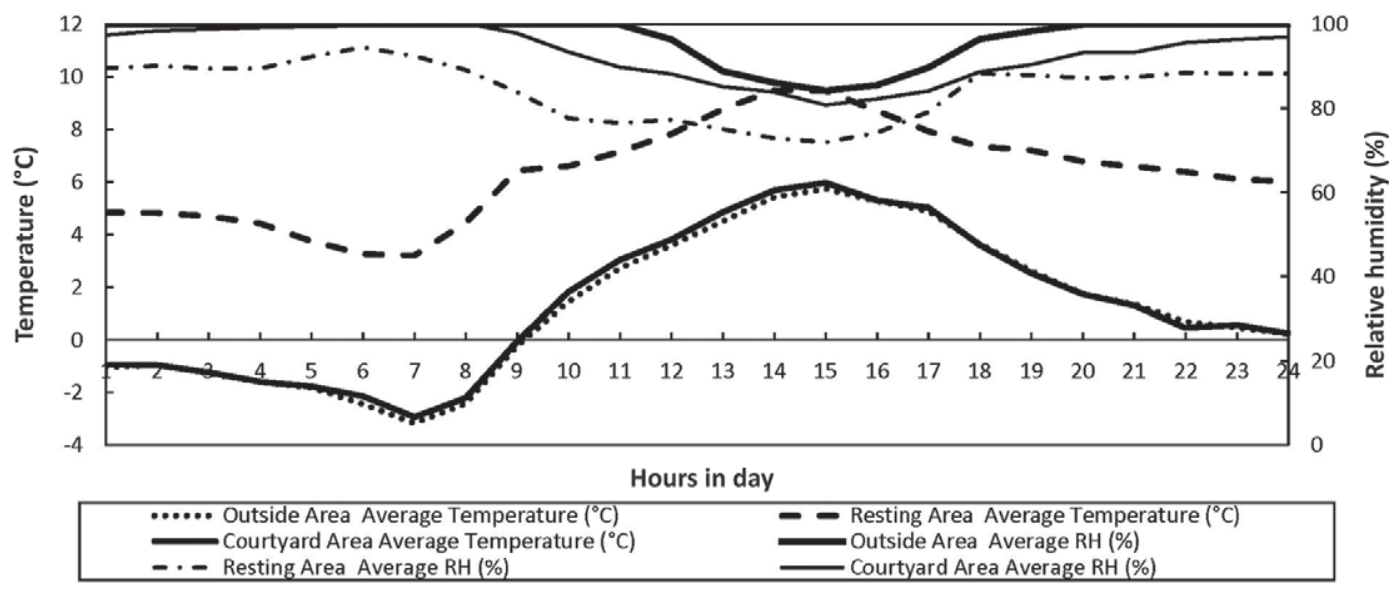

Figure 5. Distribution of hourly mean temperature and relative humidity $(\mathrm{RH})$ value for different barn areas in the winter.

1994; Ekmekyapar, 2001). This result indicates that cattle are most likely to prefer open areas if appropriate climatic conditions are provided. In a previous study, Uzal and Ugurlu (2010b) analyzed cattle behavior for $24 \mathrm{~h}$ for $1 \mathrm{yr}$ and reported the area usage of the cattle in the autumn as $3.83,11.0,0.64$, and $7.43 \mathrm{~h}$ for the freestalls, the courtyard area, the service road, and the feeding area, respectively. A high standing time could suggest a deficit in the cow's environment; for instance, cows housed in pens with an insufficient number of lying stalls, low bedding, wet bedding, or restrictive neck rails spend more time standing than those with dry stalls and less restrictive neck rails (Fregonesi et al., 2009).

In the winter, the cattle showed heavy use of the stalls from afternoon milking $(1700 \mathrm{~h})$ to $1000 \mathrm{~h}$. (Figure 4). The use of the courtyard area increased during the day (between 1000 and $1600 \mathrm{~h}$ ) by approximately
$60 \%$ and reached its highest rate $(71.8 \%)$ at $1200 \mathrm{~h}$ However, the courtyard area was not used between 1700 and $0800 \mathrm{~h}$. The reason for this result is that because the barn doors were closed during this time period due to the winter weather, the cattle could not exit to the courtyard area. After the barn doors were opened (at approximately $0850 \mathrm{~h}$ ), the increase in the use of the courtyard area indicates that when they were freed, the cattle preferred to use the courtyard area even if the weather was very cold. Phillips and Schofield (1994) reported that dairy cows spent more time resting in courtyards that had soft ground (hay bedding) and a dry and flexible ground.

In the winter, the courtyard area temperatures were approximately $4^{\circ} \mathrm{C}$ lower than the temperatures in the closed area. During the hours when the use of the courtyard area was high, the temperature of this area

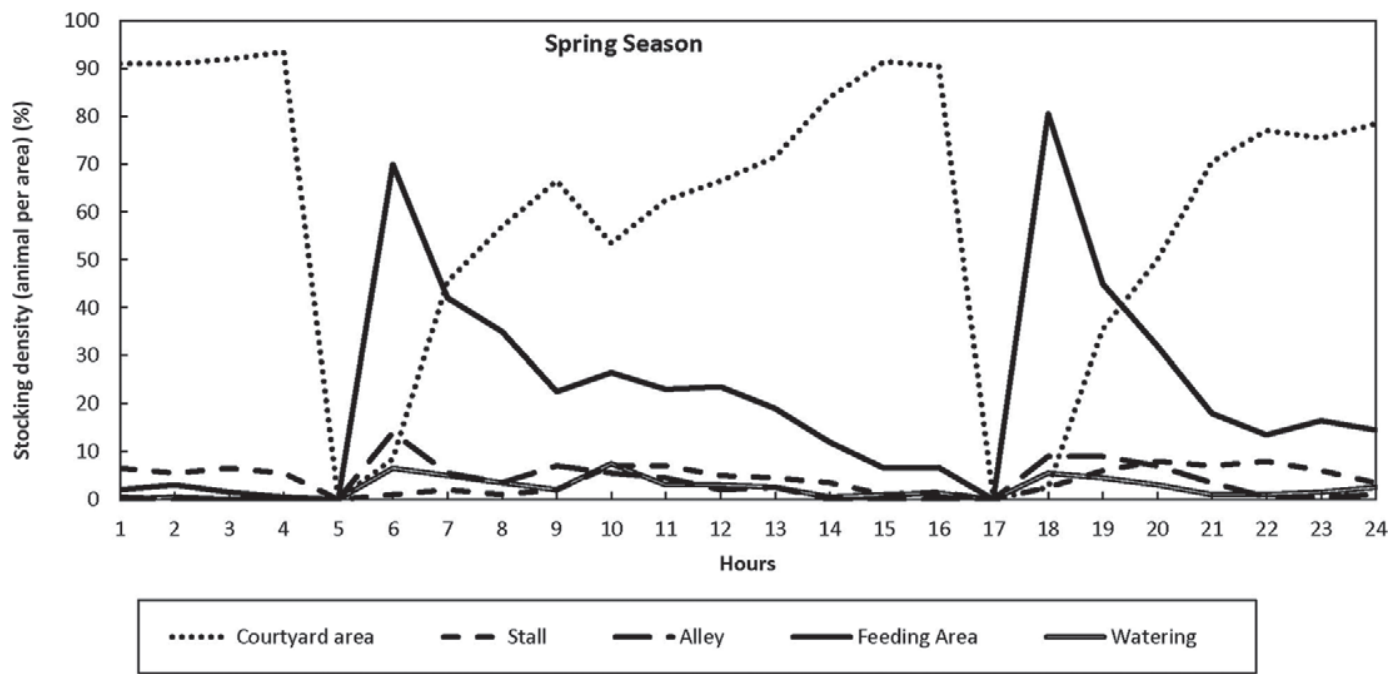

Figure 6. Distribution of mean hourly barn area usage by dairy cattle in the spring. 


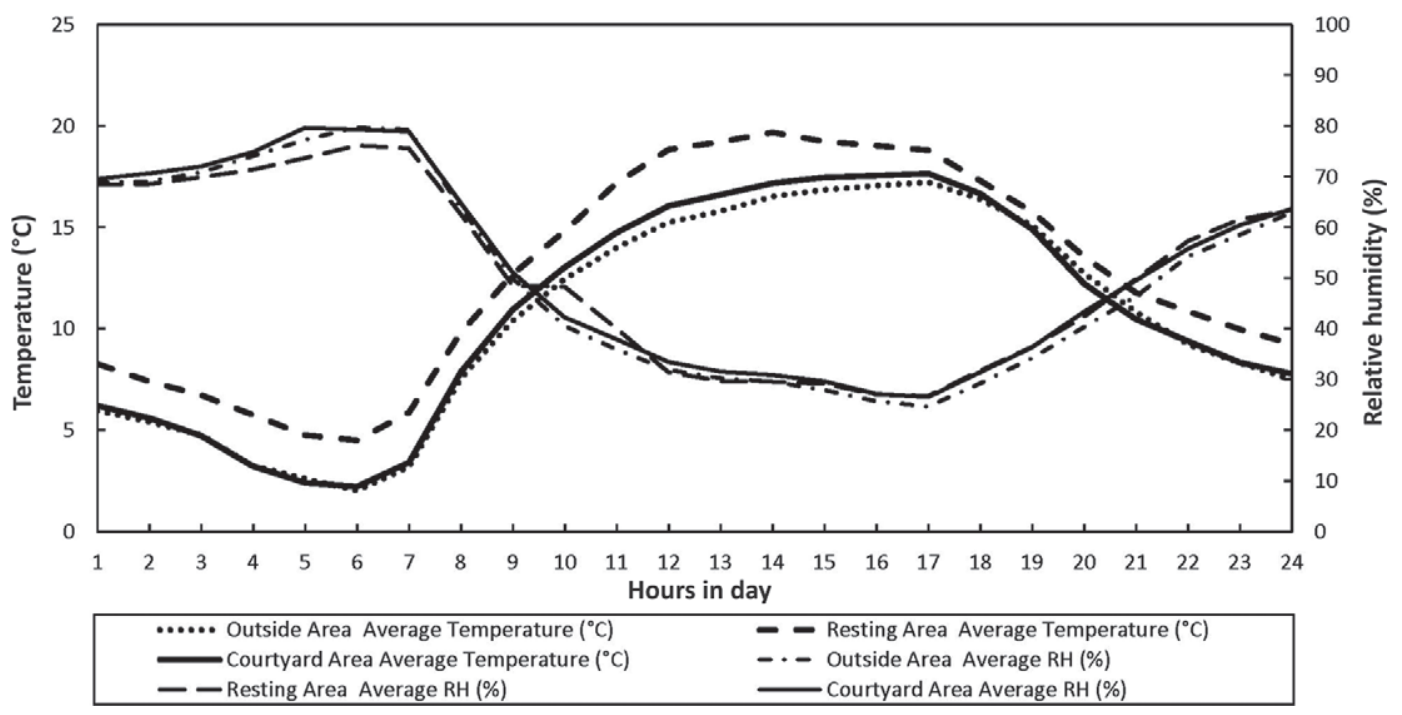

Figure 7. Distribution of hourly mean temperature and relative humidity $(\mathrm{RH})$ values for different barn areas in the spring.

was below the temperature interval appropriate for the cattle (Maton et al., 1985; Okuroğlu and Yağanoğlu; 1993; Ekmekyapar, 2001). Nevertheless, the cattle preferred to use the courtyard area. Even at the times when movement to the courtyard area was prevented, the use of the stalls was low. Because the cattle used the service road at a higher rate when they used the stalls, the use of the stalls and the use of the service road were linearly related. In all, $10 \%$ of the cattle preferred to lie on the service road rather than resting in the stalls in the winter (Figure 4).

In spring, the use of the courtyard area reached the highest rate before the morning milking $(93.5 \%$ at 0400 h). The lowest use of the courtyard occurred after milking in the afternoon (1700 h; Figure 6). The highest use of the courtyard was observed from 1300-1600 and 2100-0400 h (71-94\%). During this season, the use of the freestalls and the service road was low. Particularly at time intervals when the use of the courtyard was high, the use of the service road was $0 \%$ or close to zero. The use of the feeding area reached its highest value $(70.0 \%$ at $0600 \mathrm{~h} ; 80.5 \%$ at $1800 \mathrm{~h})$ after milking. The use of the watering area increased in direct proportion to the use of the feeding area.

The temperatures in the closed areas in the spring were 1 to $3^{\circ} \mathrm{C}$ higher than the temperature of the court-

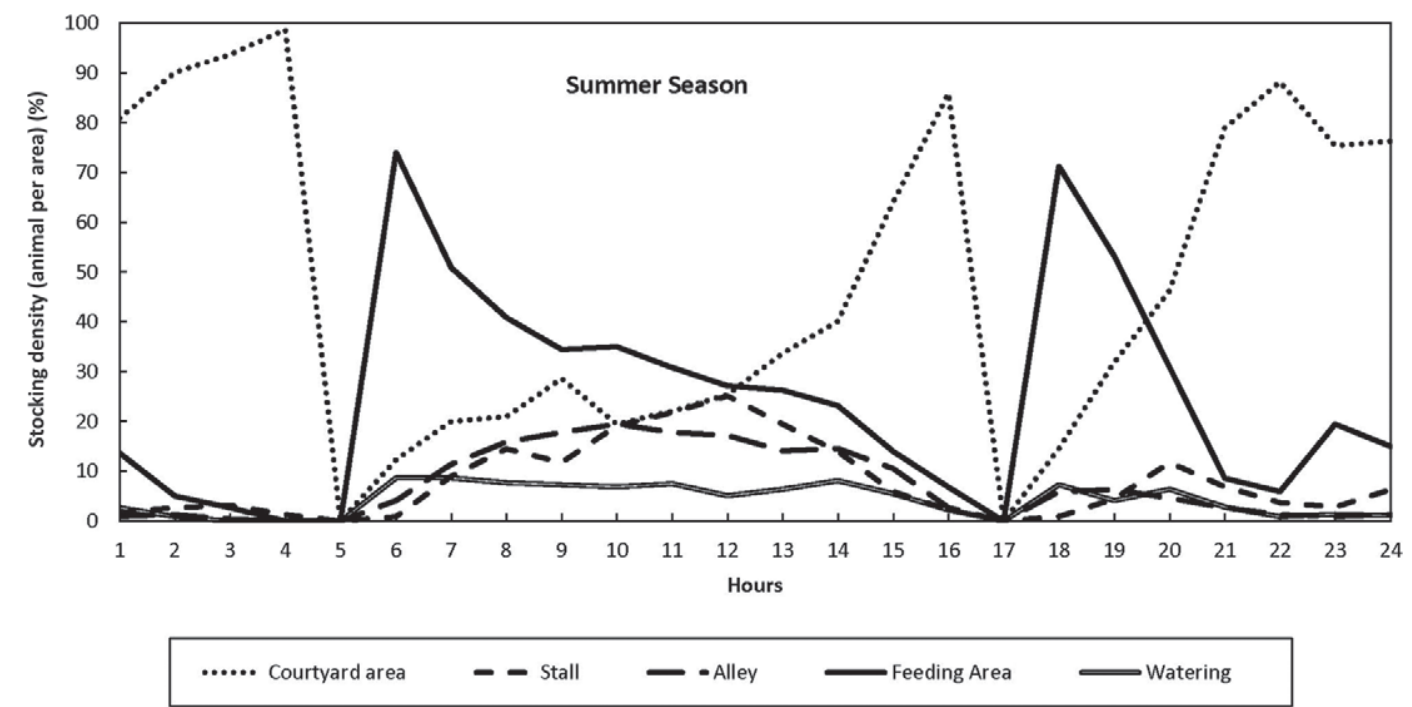

Figure 8. Distribution of mean hourly barn area usage by dairy cattle in the summer. 


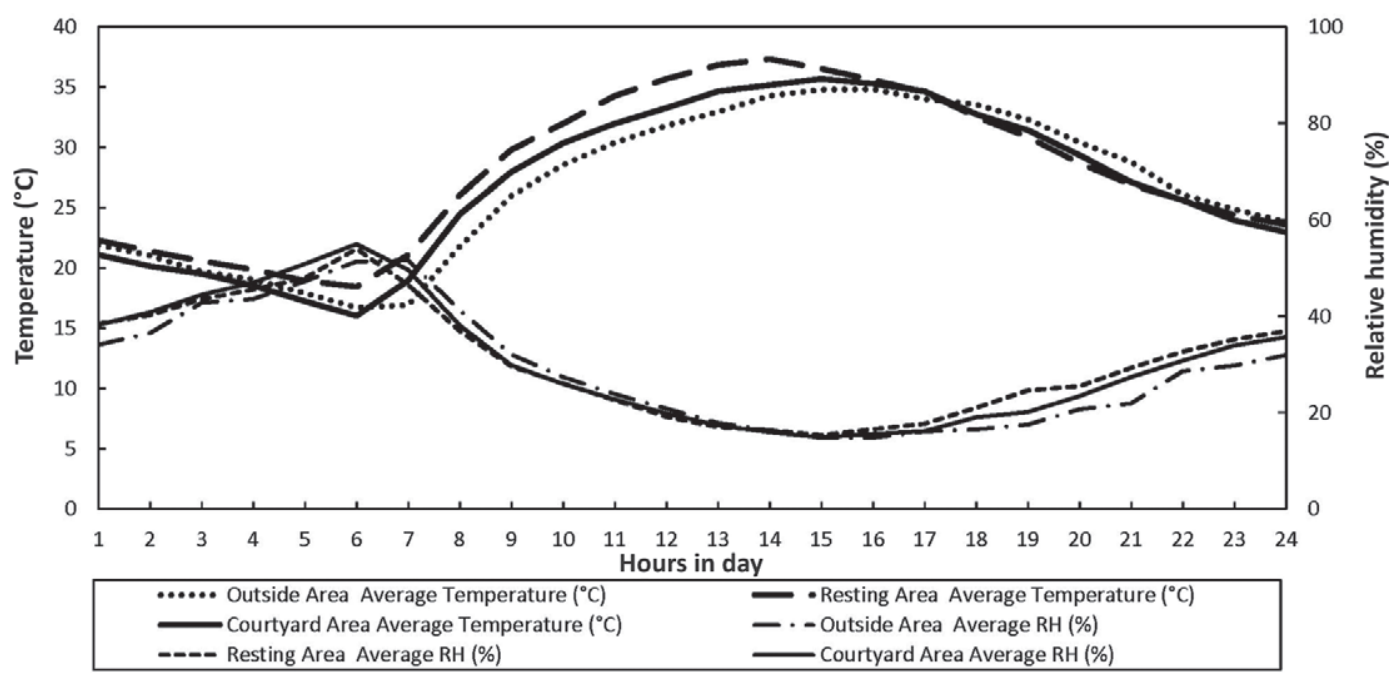

Figure 9. Distribution of hourly mean temperature and relative humidity $(\mathrm{RH})$ values for different barn areas in the summer.

yard. During the afternoon periods when the courtyard area was heavily used, the average, maximum, and minimum temperatures were $14.5,20.2$, and $7.5^{\circ} \mathrm{C}$, respectively. Heavy use of this area occurred between these hours because the temperature value was appropriate for the cows (Webster, 2004). However, the use of the area during the night cannot be explained by the temperature. This result indicates that when the cattle are free, they prefer to use open areas.

The cows generally preferred the courtyard area (mean $52.2 \%$ ) in the summer. However, they preferred to use the stalls at noon (1000-1300 h; mean 22\%; Figure 8 ). The cows moved directly to the courtyard to rest after feeding. The use of the courtyard area was inversely correlated with the use of the feeding area. Although the use of the courtyard area increased somewhat after the morning feeding, the use of the stalls also increased. At noon, the courtyard area was directly exposed to the sun. Because there was no shade in this area, the cows preferred to rest in the stalls in the closed areas, which furnished shade and were 1 to $2^{\circ} \mathrm{C}$ cooler than the courtyard (Figures 8 and 10). Mitlöhner et al. (2002) analyzed cow behavior in shaded and unshaded barn conditions and reported that the cows kept in the shade had longer resting times. Schütz et al., (2009) reported that cattle preferred to use shaded areas in the summer even during cool days and that they spent more time in these areas.

In summer, the mean temperatures in the closed area were 1 to $3^{\circ} \mathrm{C}$ higher than those in the courtyard area between 2300 and $1600 \mathrm{~h}$. However, the temperatures in the courtyard between 1700 and $2100 \mathrm{~h}$ were approximately $1^{\circ} \mathrm{C}$ higher than those in the closed area (Figure 9). This finding is one of the reasons that the

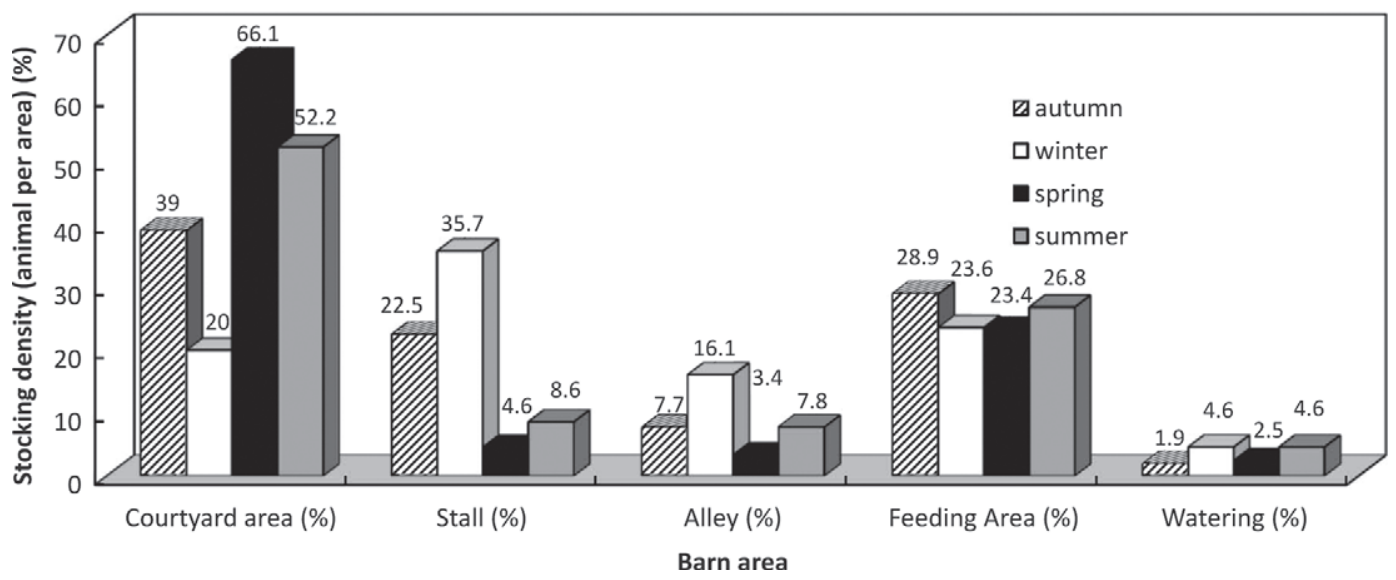

Figure 10. Distribution of mean seasonal barn area usage by dairy cattle during the year. 
use of the courtyard was low during this period. The highest maximum temperature values were $37.0,37.8$, and $39.2^{\circ} \mathrm{C}$ for the outer area, the courtyard area, and the closed area, respectively (Figure 9). Blowey (1994) reported that the critical temperatures for dairy cows were -14 and $+25^{\circ} \mathrm{C}$. Spiers (2003) reported that the lower and upper critical temperature values for dairy cows were -13.9 and $27.2^{\circ} \mathrm{C}$. The temperatures found in the study sometimes exceeded the critical temperature values. In the summer, the average $\mathrm{RH}$ values were between 15 and $52 \%, 15$ and $55 \%$, and 15 and $54 \%$ for the outer area, courtyard area, and closed area, respectively. Because the $\mathrm{RH}$ values were not between 30 and $90 \%$, the low humidity would have a negative effect on the body (Wathes et al., 1983) and the temperature regulation mechanism of the animals. The health of animals can be damaged as a result of inappropriate RH values (Wathes et al., 1983). Maton et al. (1985) reported that the optimum $\mathrm{RH}$ values should be between 60 and $80 \%$, Olgun (1988) specified an optimum range of 70 to 80\%, and Ekmekyapar (2001) and Okuroğlu and Yağanoğlu (1993) specified an optimum range of 60 to $75 \%$. In the summer, the RH values were below the appropriate values for the cattle. The negative effects of low RH can be alleviated by supplying water to the environment with a cooling fog system. The RH can be increased and the temperature can be decreased with this technique. This system ensures that the climatic conditions in the barn will be appropriate for the cattle.

The cattle generally preferred to use the courtyard area in the autumn, spring, and summer (Figure 10). In the winter, the stalls had the highest usage rate. The reason for this difference is that the barn doors were closed at night during the winter. The feeding area had the second highest usage rate in all seasons. The highest usage rate of the feeding area was observed in the autumn, whereas the lowest usage rate was observed in the winter. The time spent in feeding by the cattle was second only to the time spent in resting (Grant and Albright, 2000; Matzke, 2003; Uzal and Ugurlu, 2010a,b,c). The usage of the courtyard and the feeding area and the usage of the stalls and the service road were inversely related in all seasons (Figures 2 to 10).

The cows preferred to use the courtyard area rather than the stalls for resting. However, the stalls in freestall barns are provided as a resting place for the cattle and represent a significant part of the total construction costs. These stalls are costly, and the results of this study showed that the cattle preferred the open areas to the stalls. For this reason, good drainage of the courtyard areas and the creation of adequate areas of shade for the summer period will further increase the usage rates of these areas and be advantageous for animal comfort. Demirci (2005) conducted a study between April and
July 2004, and reported that the cattle preferred to rest in areas of the barn that received the highest winds. The resting areas in the barns should have qualities and size that allow comfortable movement of the animals. Resting behavior has an important role in increasing efficiency in dairy cattle. Matzke (2003) reported that a group of cows with a high milk yield rested 2 to 3 $\mathrm{h}$ longer than cows with an average milk yield. Uzal (2008) reported the average resting time in a freestall barn as $12.2 \mathrm{~h} / 24 \mathrm{~h}(50.9 \%)$ and $11.5 \mathrm{~h} / 24 \mathrm{~h}$ (48.0\%) for spring and summer, respectively.

\section{CONCLUSIONS}

If the cattle were free to move to the courtyard and were not confined to the barn, they preferred to use the courtyard for resting during all seasons rather than the high-cost stalls. Furthermore, the cattle preferred to use open areas for all activities observed in this study (excluding feeding and drinking) and did not use the stalls or the service road if they did not have to do so. The cattle preferred to use areas that were dry, clean, and had a soft floor with high air speed in the summer, whereas they preferred to use stable areas with low air speed in the winter. Therefore, the qualities and size of the resting areas in the barns should allow comfortable movement of the animals. In addition, well-designed courtyard areas (creation of adequate shade areas for the summer period and good drainage of the courtyard areas) will further increase the usage rates of these areas and will be advantageous for animal comfort. For these reasons, it is very important that new barn designs incorporate area preferences and the comfort of the cattle rather than high-cost investments. Accordingly, the bases for these plans should include economy, animal welfare and comfort, and milk yield.

\section{REFERENCES}

Absmanner, E., C. Rouha-Mülleder, T. Scharl, F. Leisch, and J. Troxler. 2009. Effects of different housing systems on the behaviour of beef bulls - An on-farm assessment on Austrian farms. Appl. Anim. Behav. Sci. 118:12-19.

Adams, R. S. 1992. Reducing heat stress on dairy cows. Pennsylvania State University, June 1992. Taken from National Dairy Database. Accessed Nov. 8, 2012. http://www.clemson.edu/psapublishing/ disaster/Drought/Drout6.htm.

Barberg, A. E., M. I. Endres, J. A. Salfer, and J. K. Reneau. 2007. Performance and welfare of dairy cows in an alternative housing system in Minnesota. J. Dairy Sci. 90:1575-1583.

Blowey, R. 1994. Dairy cow housing. Pages 305-337 in Livestock Housing. C. M. Wathes and D. R. Charles, ed. Cambridge University Press, Cambridge, UK.

Brown-Brandl, T. M., R. A. Eigenberg, J. A. Nienaber, and G. L. Hahn. 2003. Shade effects on physiological responses of feeder cattle. Page 107 in Interactions between Climate and Animal Production. N. Lacetera, U. Bernabucci, H. H. Khalifa, B. Ronchi, and A. Nardone, ed. Wageningen Academic Publishers, Wageningen, the Netherlands. 
Calamari, L., M. Speroni, E. Frazzi, L. Stefanini, and G. Licitra. 2003. Productive and metabolic response of dairy cows raised in barn equipped with fans and misters during the summer season. Page 108 in Interactions between Climate and Animal Production. N. Lacetera, U. Bernabucci, H. H. Khalifa, B. Ronchi, and A. Nardone, ed. Wageningen Academic Publishers, Wageningen, the Netherlands.

Collier, R. J., C. Coppola, and A. Wolfgram. 2003. Novel approaches for the alleviation of climatic stress in farm animals. Page 61 in Interactions between Climate and Animal Production. N. Lacetera, U. Bernabucci, H. H. Khalifa, B. Ronchi, and A. Nardone A., ed. Wageningen Academic Publishers, Wageningen, the Netherlands.

Cook, N. B., T. B. Bennett, and K. V. Nordlund. 2005. Monitoring indices of cow comfort in free-stall-housed dairy herds. J. Dairy Sci. $88: 3876-3885$.

Cook, N. B., R. L. Mentink, T. B. Bennett, and K. Burgi. 2007. The effect of heat stress and lameness on time budgets of lactating dairy cows. J. Dairy Sci. 90:1674-1682.

Damasceno, J. C., F. Baccari Júnior, and L. A. Targa. 1999. Behavior responses of Holstein cows with constant or limited access to shade. Pesquisa Agropecuária Brasileira 34:709-715.

Demirci, B. 2005. Serbest Duraklı Ahırlarda Sağmal İnekler İçin Kullanılan Çeşitli Yatma Materyallerinin Karşılaştırılması. MS Thesis. Cukurova University, The Institute of Natural and Applied Sciences, Adana, Turkey.

Ekmekyapar, T. 1991. Hayvan Barınaklarında Çevre Koşullarının Düzenlenmesi. Agricultural Faculty Lecturer Publication No. 306. Atatürk University, Erzurum, Turkey.

Ekmekyapar, T. 2001. Tarımsal Yapılar. Agricultural Faculty Lecturer Publication No. 204. Atatürk University, Erzurum, Turkey.

Endres, M. I., and A. E. Barberg. 2007. Behavior of dairy cows in an alternative bedded-pack housing system. J. Dairy Sci. 90:41924200.

Frazzi, E., and F. Calegari. 2003. Behaviour of dairy cows in hot season in a barn equipped with automatic milking system. Page 111 in Interactions between Climate and Animal Production. N. Lacetera, U. Bernabucci, H. H. Khalifa, B. Ranchi, and A. Nardone, ed. Wageningen Academic Publishers, Wageningen, the Netherlands.

Fregonesi, J. A., C. B. Tucker, and D. M. Weary. 2007. Overstocking reduces lying time in dairy cows. J. Dairy Sci. 90:3349-3354.

Fregonesi, J. A., M. A. G. von Keyserlingk, C. B. Tucker, D. M. Veira, and D. M. Weary. 2009. Neck-rail position in the freestall affects standing behavior, udder and stall cleanliness. J. Dairy Sci. 92:1979-1985.

Grant, R. J., and J. L. Albright. 2000. Feeding behaviour. Pages 365382 in Farm Animal Metabolism and Nutrition. J. P. F. D'Mello, ed. CABI Publishing, New York, NY.

Haley, D. B., J. Rushen, and A. M. de Passillé. 2000. Behavioural indicators of cow comfort: Activity and resting behaviour of dairy cows in two types of housing. Can. J. Anim. Sci. 80:257-263.

Hayasaka, K., T. Masubuchi, M. Kamo, H. Kawamoto, and H. Shimonasako. 2002. Effects of localized air flowing system in free stalls on behavior of lactating cows in a hot environment. Bull. Nat, Inst. Livest. Grassl. Sci. 1:49-54.

Hernández-Lloreda, M. V., and F. Calmenares. 2006. The utility of generalizability theory in the study of animal behaviour. J. Anim. Behav. 71:983-988.

Martin, P., and P. Bateson. 1993. Measuring Behaviour. Cambridge University Press, Cambridge, UK.

Maton, A., J. Daelemans, and J. Lambrecht. 1985. Housing of Animals. Elsevier Science Publishers BV, Amsterdam, the Netherlands.

Mattachini, G., E. Riva, and G. Provolo. 2011. The lying and standing activity indices of dairy cows in free-stall housing. Appl. Anim. Behav. Sci. 129:18-27.

Matzke, W. C. 2003. Behavior of large groups of lactating dairy cattle housed in a free stall barn. MS Thesis. Univ. of Nebraska, Lincoln.

Mitlöhner, F. M., M. L. Galyean, and J. J. McGlone. 2002. Shade effects on performance, carcass traits, physiology, and behavior of heat-stressed feedlot heifers. J. Anim. Sci. 80:2043-2050.
Mitlöhner, F. M., J. L. Morrow-Tesch, S. C. Wilson, J. W. Dailey, and J. J. McGlone. 2001. Behavioral sampling techniques for feedlot cattle. J. Anim. Sci. 79:1189-1193.

Okuroğlu, M., and A. V. Yağanoğlu. 1993. Kültürteknik, Atatürk Üniversitesi Ziraat Fakültesi Ders Yayınları No. 157. Atatürk University, Erzurum, Turkey.

Olgun, M. 1988. Süt Sığırı Ahırlarında Optimum Çevre Koşulları Hasad Aylık Tarım Dergisi 4:21-24.

Overton, M. W., D. A. Moore, and W. M. Sischo. 2003. Comparison of commonly used indices to evaluate dairy cattle lying behavior. ASAE Paper No. 701P0203. American Society of Agricultural Engineers (ASAE), St. Joseph, MI.

Overton, M. W., W. M. Sischo, G. D. Temple, and D. A. Moore. 2002 Using time-lapse video photography to assess dairy cattle lying behavior in a free-stall barn. J. Dairy Sci. 85:2407-2413.

Phillips, C. J. C., and S. A. Schofield. 1994. The effect of cubicle and straw yard housing on the behaviour, production and hoof health of dairy cows. Anim. Welf. 3:37-44.

Phillips, S. B., S. P. Arya, and V. P. Aneja. 2004. Ammonia flux and dry deposition velocity from near-surface concentration gradient measurements over a grass surface in North Carolina. Atmos. Environ. 38:3469-3480.

Provolo, G., and E. Riva. 2008. Daily and seasonal patterns of lying and standing behaviour of dairy cows in a freestall barn. In Proc. International Conference "Innovation Technology to Empower Safety, Health and Welfare in Agriculture and Agro-Food Systems," Ragusa, Italy.

Robarge, W. P., J. T. Walker, R. B. McCulloch, and G. Murray. 2002. Atmospheric concentrations of ammonia and ammonium at an agricultural site in the southeast United States. Atmos. Environ. $36: 1661-1674$

Schütz, K. E., A. R. Rogers, N. R. Cox, and C. B. Tucker. 2009. Dairy cows prefer shade that offers greater protection against solar radiation in summer: Shade use, behaviour, and body temperature. Appl. Anim. Behav. Sci. 116:28-34.

Shultz, T. A. 1984. Weather and shade effects on cow corral activities J. Dairy Sci. 67:868-873.

Spiers, E. D. 2003. How cows dissipate heat. Accessed Nov. 20, 2012.ftp:// cals.arizona.edu/dept/animsci/trialpictures/2000HOAcowheat. pdf.

St-Pierre, N. R., B. Cobanov, and G. Schnitkey. 2003. Economic losses from heat stress by US livestock industries. J. Dairy Sci 86(Suppl.):E52-E77.

Tucker, C. B., A. R. Rogers, G. A. Verkerk, P. E. Kendall, J. R. Webster, and L. R. Matthews. 2007. Effects of shelter and body condition on the behaviour and physiology of dairy cattle in winter. Appl. Anim. Behav. Sci. 105:1-13.

Ugurlu, N., and S. Uzal. 2004. Süt Sığırı barınaklarının tasarımında mevsimsel etkiler. Selçuk Üniversitesi Ziraat Fakültesi Dergisi 18:73-79.

Uzal, S. 2008. Serbest ve serbest duraklı süt sığırı barınaklarında hayvanların alan kullanımı ve zaman bütçesine mevsimlerin etkisi. PhD Thesis. Entitute of Natural and Applied Sciences, Department of Farm Structure and Irrigation, Selçuk University, Konya, Turkey.

Uzal, S., and N. Ugurlu. 2009. Serbest ve serbest durakl süt sığırı barınaklarında sığırların zaman bütçesi ve barınak alan kullanımları. Selçuk J. Agric. Food Sci. 23:27-37.

Uzal, S., and N. Ugurlu. 2010a. The time budget of dairy cows as affected by season and housing system. J. Int. Environ. Application Sci. 5:638-647.

Uzal, S., and N. Ugurlu. 2010b. The dairy cattle behaviors and time budget and barn area usage in freestall housing. J. Anim. Vet. Adv. 9:248-254.

Uzal, S., and N. Ugurlu. 2010c. The effects of seasons on the time budget and area usage of animals in open loose dairy cattle housing. J. Anim. Vet. Adv. 9:88-95.

Walker, J. T., W. P. Robarge, A. Shendrikar, and H. Kimball. 2006. Inorganic PM2.5 at a U.S. agricultural site. Environ. Pollut. 139:258-271. 
Wathes, C. H., C. D. R. Jones, and A. J. F. Webster. 1983. Ventilation, air hygiene and animal health. Vet. Rec. 133:554-559.

Weary, D. M., and D. Fraser. 2006. Scientific methods of assessing animal well-being. SCAW Newsletter, Volume 28 Number 2. Accessed Dec. 28, 2011. http://www.scaw.com/assets/files/1/files/06summer-newsletter-.pdf.

Webster, A. J. F. 1994. Comfort and injury. Pages 49-67 in Livestock Housing. C. M. Wathes and D. R., Charles, ed. University Press, Cambridge, UK.
WMO (World Meteorological Organization). 2012. Weather and climate and animal production. Chapter 12 in Guide to Agricultural Meteorological Practices. Accessed Mar. 1, 2012. http://www.wamis.org/agm/gamp/GAMP_Chap12.pdf.

Zähner, M., L. Schrader, R. Hauser, M. Keck, W. Langhans, and B. Wechsler. 2004. The influence of climatic conditions on physiological and behavioural parameters in dairy cows kept in open stables. Anim. Sci. 78:139-147. 